UPLATNĚNÍ TRANSKULTURNÍHO PŘÍSTUPU V AZYLOVÝCH ZAŘÍZENÍCH A ZAŘÍZENÍCH PRO ZAJIŠTĚNÍ CIZINCU゚ V ČESKÉ REPUBLICE

\title{
THE APPLICATION OF THE TRANSCULTURAL APPROACH IN THE ASYLUM CENTERS AND THE FACILITIES FOR THE DETENTION OF FOREIGNERS IN THE CZECH REPUBLIC
}

\author{
*Natália Beharková, **Ada Tržilová \\ *Katedra ošetřovatelství, Lékařská fakulta, Masarykova \\ univerzita Brno \\ **Zařízení pro zajištění cizinců, Poštorná
}

\begin{abstract}
Abstrakt
Přítomnost cizinců na území České republiky byla i v dávné době zcela přirozená, měnil se jen původ cizinců a důvod jejich pobytu. Přispěvek nastiňuje problematiku transkulturního prístupu $v$ azylových zařízeních, zařízeních pro zajištění cizinců a rozširuje transkulturní pojetí - problematiku cizinců žádajících na území ČR o mezinárodní ochranu (např. V nemocnicích požádalo o mezinárodní ochranu $\mathrm{v}$ roce 2008 - 15 cizích státních příslušníků). (Ministerstvo vnitra České republiky, Mezinárodní ochrana, 2009) Nastiňuje se zde problematika migrace a stručný popis legislativního rámce $v$ kontextu cizinecké problematiky. V závěru příspěvku jsou charakterizována jednotlivá azylová střediska a zařízení pro zajištění cizinců.
\end{abstract}

\section{Abstract}

The presence of foreigners in the Czech Republic has a long history, there were only some changes of the foreigner's origin and the reason for staying. The article is 
an introduction to the issue of transcultural care facilities to ensure that foreigners and extending the concept of transcultural issues demanding foreigners in the czech Republic for International protection (e.g. in hospitals asked for the International protection - 15 foreign nationals in 2008) (Ministry of the Interior of the Czech Republic, Asylum, 2009). It outlines the problems of migration and it is a brief description of the legislative framework in the context of Foreign affairs. In the end there are characterized particular Asylum centers and Facilities for the Detention of Foreigners in the Czech Republic.

\section{Klíčová slova}

azylová zařizení, cizinec, legislativa, migrace, transkulturní př́stup

\section{Key words}

Asylum facilities, Foreigners, Legislation, Immigration, Transcultural approach

\section{Úvod}

Výrazným prvkem ovlivňujícím celosvětové dění je migrace osob. "Migrace obyvatelstva je součástí dějin lidské společnosti. I na území dnešní České republiky se spolu v minulosti mísily přistěhovalecké slovanské kmeny s dříve usedlým keltským, germánským a jiným obyvatelstvem. Velkým zdrojem migrací vždy byly války, ekonomické rozdíly mezi zeměmi a politické převraty." (Ivanová, Špirudová, Kutnohorská, 2005, s. 84) "Migrace je definována jako přesun jednotlivců i skupin v prostoru." (MV ČR, Terminologický slovník) Její dopad je 
patrný ve všech oblastech života na zemi, má přímý dopad na demografický vývin, socio-ekonomické, ale i kulturní změny obyvatel jednotlivých zemí. Samotná migrace může s sebou nést určitá negativa, především z hlediska bezpečnosti, ale i určitá pozitiva, která mohou řešit situaci dané společnosti (např. uplatnění se na trhu práce v chybějících oblastech, ovlivnění nepříznivé demografické situace aj.) • "S ekonomickým rozvojem se intenzita migrace neustále zvyšuje." (MV ČR, Terminologický slovník) Pro samotné migranty je důležitý faktor, proč opouštějí svou vlast, zda tak činí dobrovolně nebo jsou určitým způsobem či důvodem $k$ migraci nuceni. Z hlediska legality přesunu a pobývání cizinců na území ČR můžeme migraci charakterizovat jako legální a nelegální. Tak jako všude ve světě i Česká republika se setkává s nelegální migrací. "Nelegální migrace je fenoménem, který může v cílových zemích zásadním způsobem ohrozit vnitřní stabilitu a bezpečnostní situaci. Z toho důvodu jsou opatření v oblasti potírání nelegální migrace jedním ze zásadních témat řešených v rámci migrační politiky České republiky. Jako nelegální migraci je třeba vnímat nejen neoprávněný vstup na území státu či jeho neoprávněné opuštění, ale také neoprávněný pobyt na území nebo pobyt $v$ rozporu s účelem, pro který bylo vydáno pobytové oprávnění." (MV ČR, Přístup k nelegální migraci v České republice a Evropské unii, 2008)

\section{Cíl práce}

Cílem práce je přiblížit problematiku cizinců žijících na území České republiky v kontextu ne/legální migrace, legislativního rámce a způsobu jejich života do doby ne/udělení mezinárodní ochrany event. jejich zajištění 
v zařízení pro zajištění cizinců. Jedním z cílů transkulturního ošetřovatelství je poskytovat vhodnou, smysluplnou, účinnou a individualizovanou podporou ve zdraví a nemoci. Pro lepší pochopení a rozšírení transkulturního aspektu péče o cizince je nezbytné poznat základní právní aspekty, některá východiska vymezující důvody migrace, její dopad na společnost a možnosti pomoci cizincům, kteří opouští své domovy.

\section{Východiska}

Přítomnost cizinců na území České republiky byla i v dávné době zcela přirozená, měnil se jen původ cizinců a důvod jejich pobytu (původně výměnné, vzdělávací, pracovní pobyty bývalého socialistického bloku nahradil "po pádu železné opony" přesun migrantů ze zemí původu za lepšími podmínkami "směrem na západ", stali jsme se tak spíš tranzitní zemí). "V posledních letech se stala Česká republika zemí, která je pro cizince migrující za prací a obchodem cílovou zemí pro dlouhodobé Či trvalé usazení." (MV ČR, Migrační politika České republiky, 2008)

Cizincem je fyzická osoba, která není státním občanem České republiky, včetně občana Evropské unie (tj. cizincem je i občan EU). Ředitelství služby cizinecké a pohraniční policie Ministerstva vnitra ČR evidovalo k 31. 7. 2009 celkový počet cizinců na území ČR - 439 762. Z toho mělo trvalý pobyt 176 508 osob (mužů 93598 a žen 82 910), ostatní typy pobytu byly evidovány u 263254 (mužů $168 \quad 840$ a žen 94 414). Nejvíce cizinců bylo z Ukrajiny (133 773 - trvalý pobyt 42 429, ostatní typy pobytu 91 344), Slovenska (76956 - trvalý pobyt 25 813, ostatní typy pobytu 51 143), Vietnamu (60 998 - trvalý 
pobyt 35 402, ostatní typy pobytu 25 596), Ruska (29 144 trvalý pobyt 12 481, ostatní typy pobytu 16 663), Polska (20 700 - trvalý pobyt 11 039, ostatní typy pobytu 9 661), Německa (15 863 - trvalý pobyt 4 399, ostatní typy pobytu 11 464), Moldavska (10 758 - trvalý pobyt 2 242, ostatní typy pobytu 8 516) aj. (Čsú, 2009, Cizinci podle typu pobytu, pohlaví a státního občanství - k 31. 7. 2009)

\section{Analýza problému}

Pokud bychom se na problematiku multikultury/transkultury podívali v širším kontextu, nesmíme opomíjet azylová zařízení a zařízení pro zajištění cizinců. Kde jinde najdeme tolik různých národností, etnik nebo náboženských skupin než zde, kde jinde se tak výrazně mísí různé kultury, zvyky, tradice, jazyky aj. Status žadatele o mezinárodní ochranu, člověka v tak cizím prostředí rozhodně není jednoduchý. V jediném lidském osudu, mnohdy velmi nelehkém, se prolíná dosavadní způsob života, aktuální přítomnost přežívaní mezi minulostí a nejasnou budoucností. Mnozí jsou majitelé jediné naděje, naděje na nový a snad i o něco lepší život. Pro lepší analýzu a přiblížení problematiky cizinců $v$ azylových zařízeních a v zařízeních pro zajištění cizinců (dále jen zzC) je nutno zmínit:

- legislativní rámec;

- cíl, účel a charakteristiku jednotlivých typů azylových zařízení a ZZC;

- charakteristiku transkulturního přístupu v azylových zařizeních a ZzC. 


\section{Legislativní rámec}

Legislativně byl pobyt cizinců na území České republiky řízen několika zákony, jejichž znění a platnost byly ovlivněny i rozdělením dřívější ČSSR, později ČSFR na dva samostatné státy, Českou republiku a Slovenskou republiku. Zákon Č. 68/1965 Sb., o pobytu cizinců na území Československé socialistické republiky, byl platný do 30. 9. 1992, poté byl nahrazen zákonem č. 123/1992 Sb., o pobytu cizinců na území Československé federativní republiky s platností od 1.10 . 1992 až do 1. 1. 2000. Po rozpadu ČSFR byl zákon převzat do české Sbírky zákonů. Od 1. 1. 2000 byl původní zákon nahrazen Zákonem č. $326 / 1999 \mathrm{Sb} .$, o pobytu cizinců (zákon byl upraven několika novelami, aby byla zajištěna kompatibilita legislativy ČR a EU). (ČSÚ, Demografické aspekty života cizinců, 2003)

V současnosti se legislativně řídí pobyt cizince na území ČR Zákonem č. 379/2007 Sb., kterým se mění Zákon č. 326/1999Sb., - pobytu cizinců na území České republiky a o změně některých zákonů, ve znění pozdějších předpisů.

V souvislosti s pobytem cizinců na území ČR je nutné zmínit azylovou problematiku, která se řídí legislativním rámcem Zákonem Č. $165 / 2006$ Sb., o azylu s platností od 1.9. 2006 (pưvodně Zákon č. 325/1999 Sb., O azylu a o změně Zákona Č. 283/1991 Sb., o policii České republiky - t. Č. už nový zákon - Zákon Č. 273/2008 o Policii České republiky). Samotná azylová problematika se začala výrazně řešit $v$ bývalém Československu až po roce 1989.

"Azyl je ochranný pobyt, který stát poskytuje státnímu příslušníku třetí země nebo osobě bez státní příslušnosti v souvislosti s jejím pronásledováním zpravidla $z$ důvodů politických (specifikace dle platné legislativy ČR). Azylant 
je cizinec, kterému byl udělen azyl, a to po dobu platnosti rozhodnutí o udělení azylu." (MV ČR, Terminologický slovník) "Zahájení správního řízení je vázáno na prohlášení cizince, ze kterého je zřejmý úmysl požádat o udělení mezinárodní ochrany. Takové prohlášení lze učinit pouze na území České republiky písemně nebo ústně do protokolu. Prohlášení je možno učinit na hraničním přechodu, v přijímacím středisku, na odboru cizinecké a pohraniční policie za podmínky, že se cizinec dostavil dobrovolně, v zařízení pro zajištění cizinců, ve zdravotnickém zařízení $v$ průběhu hospitalizace nebo ve vězení. Cizinec má povinnost dostavit se do 24 hodin od prohlášení do přijímacího střediska, kde podá žádost o mezinárodní ochranu. Výjimkou jsou pouze situace, kdy se z objektivních důvodů dostavit nemůže (hospitalizace, vězení). V těchto případech navštíví cizince pracovník Ministerstva vnitra České republiky a sepíše s ním žádost o mezinárodní ochranu v místě jeho aktuálního pobytu." (MV ČR, Průběh správního řízení o udělení mezinárodní ochrany, 2008)

Za rok 2008 bylo V ČR evidováno 1656 žadatelů o mezinárodní ochranu (první žádost podalo 1060 cizinců a opakovanou žádost 596 osob). Nejvíce žádostí bylo zaznamenaných u cizinců pocházejících z:

- Ukrajiny 321 (z toho muži 210 a ženy 74, děti od 0 - 17 let 37$)$;

- Turecka 251 (z toho muži 153 a ženy 26, děti od 0 - 17 let $72)$;

- Mongolska 193 (z toho muži 100 a ženy 71, děti od 0 - 17 let 22);

- Vietnamu 108 ( z toho muži 70 a ženy 31, děti od 0 - 17 let 7) ; 
- Běloruska 79 ( z toho muži 55 a ženy 12, děti od 0 - 17 let 12);

- Ruska 79 ( z toho muži 42 a ženy 19, děti od 0 - 17 let 18);

- Kazachstánu 73 ( z toho muži 21 a ženy 12, děti od 0 - 17 let 40). (MV ČR, Statistická zpráva - žadatelé o mezinárodní ochranu a azylanti, 2009)

V roce 2008 bylo v ČR také evidováno 863 dublinských případů. (MV ČR, Počet dublinských případi̊ květen 2004 - prosinec 2008, 2009) "Dublinský systém je označení, používané pro mechanismus, kterým je určován stát odpovědný za posouzení žádosti o azyl (mezinárodní ochranu) podané na území členských států Evropských společenství státním přislušníkem třetího státu. (MV ČR, Terminologický slovník)

"Na problematiku cizinců, žadatelů o mezinárodní ochranu, azylanti̊ a osob požívajících jedné z další forem ochrany, a to at již doplňkové, či dočasné, by měli být připraveni i občané majoritní společnosti, aby svým chováním přispěli k jejich rychlejší integraci (začlenění do běžného života)." (Šišková, 2008 , s. 59)

\section{Azylová zařízení}

Žadatelé o mezinárodní ochranu jsou umístněni do azylových zařízení. Podle účelu se azylová zařízení dělí na:

- přijímací střediska - slouží k prvotnímu ubytování nově přichozích žadatelů o mezinárodní ochranu (udělení mezinárodní ochrany může být formou azylu nebo doplňkové ochrany) a saturace všech základních potřeb, až do ukončení vstupní procedury. Vstupní procedura je povinná a spočívá v identifikaci totožnosti prováděnou 
cizineckou policií, zahájením řízení o udělení mezinárodní ochrany správním orgánem, komplexní zdravotní prohlídce, vstupního pohovoru a sociálního šetření. Přijímací středisko je kvůli karanténnímu důvodu uzavřeného typu. K dispozici jsou žadatelům - mezinárodní ochranu služby sociální, psychologické, právní, zdravotní a jiné dle potřeb. Přijímací střediska jsou na území ČR umístěna na mezinárodním letišti Praha - Ruzyně a ve Vyšních Lhotách;

- pobytová střediska - zde jsou ubytováni všichni žadatelé, kteří mají vstupní procedury ukončené a čekají na konečné rozhodnutí o udělení mezinárodní ochrany. Soubor služeb je obdobný přijímacím střediskům s výjimkou, že jde o otevřená zařízení. Strava je žadatelům zajištěna dvěma způsoby - bud'to je žadatelům poskytována, nebo dostávají klienti finanční příspěvek, ze kterého si stravování individuálně zajištují sami. Pobytová střediska jsou na území ČR umístěna $v$ Kostelci nad Orlicí a Havířově. Zastávka u Brna je pobytové i integrační středisko.

- integrační azylová střediska - zde jsou ubytováni klienti, kterým byla přiznána mezinárodní ochrana a zde požádali o dočasné ubytování. Osoby s přiznanou mezinárodní ochranou mají stejná práva a povinnosti v oblasti uplatnění se na trhu práce a ve zdravotně sociální oblasti, jako občané ČR. V integračním azylovém středisku je ubytování na základě smlouvy a hradí si je klient sám. Smlouva je ukončena okamžikem, kdy klient získá díky státnímu integračnímu programu, nebo individuálně, trvalé bydlení. Délka setrvání v tomto typu střediska je nejvíce 18 měsíců 
a slouží především k osvojení českého jazyka, získání samostatného bydlení a zaměstnání. Integrační azylová střediska jsou na území ČR umístěna $v$ Jaroměři, Předlicích, Zastávce u Brna, Brně a České Lípě (SUZ MV ČR, Správa uprchlických zařízení Ministerstva vnitra České Republiky, 2009)

"Přijímací středisko Vyšní Lhoty (Moravskoslezský kraj) přestane ke dni 31. 11. 2009 fungovat jako přijímací středisko. Stávající Pobytové středisko Zastávka (Jihomoravský kraj) je nyní po rekonstrukci a od 1. 11. 2009 bude sloužit jako přijímací středisko. Od 1. 12. 2009 budou tedy ve správě SUZ dvě přijímací a dvě pobytová střediska a dvě zařízení pro zajištění cizinců, vždy jedno v Čechách a jedno na Moravě." (SUZ MV ČR, Správa uprchlických zařízení Ministerstva vnitra České Republiky, 2009)

\section{Zařízení pro zajištění cizinců}

V zařízeních pro zajištění cizincư jsou umístněny osoby, které se dopustily konánípřestupku, a které jsou v rozporu s platnou legislativou ČR a EU. Zajištění těchto osob je opatřením, kterým má být cizincưm zabráněno $v$ dalším porušování zákona a zajištěno jejich vycestování z území ČR, a to po nabytí právní moci a rozhodnutí o správním vyhoštění. "Zajištěny mohou být jen osoby ve věku nad 15 let, a to na dobu maximálně 180 dní." (SUZ MV ČR, Správa uprchlických zařizení Ministerstva vnitra České Republiky, 2009) V současnosti jsou na území ČR dvě zařízení pro zajištění cizinců (dále jen ZZC) Bělá - Jezová (Bělá pod Bezdězem) a Poštorná (Břeclav). Cizincưm jsou zde poskytovány zdravotněsociální služby, psychologické a právní poradenství, ubytování, stravování a hygienické prostředky. 
Provoz jednotlivých azylových zařizení a zařízení pro zajištění cizinců zabezpečuje správa uprchlických zařízení dále jen SUZ), která byla zřízena v roce 1996.

"Žadatelům o mezinárodní ochranu je zdravotní péče poskytována v rozsahu veřejného zdravotního pojištění. Pojištěni jsou u Všeobecné zdravotní pojišt’ovny a plátcem pojistného je stát. "Azylanti" jsou pojištěni v rozsahu veřejného zdravotního pojištění a mají možnost výběru zdravotní pojištoovny za stejných podmínek jako občané České republiky. Cizincům umístěným v zařízení pro zajištění cizinců je poskytována nezbytná a neodkladná zdravotní péče, náklady za zdravotní péci hradí SUZ z vlastního rozpočtu." (SUZ MV ČR, Výroční zpráva za roky 2007, 2008) Nejčastěji jsou prostředky za zdravotní péči $v$ azylových zařízeních a zařízeních pro zajištění cizinců vynaloženy na položky za laboratorní vstupy, Rtg. vstupní vyšetření, léky, psychiatrické konzilium aj.

\section{Uplatnění transkulturního přístupu $v$ azylových zařízeních} a ZZC:

- holistické pojetí s respektem individuality každého klienta;

- ubytování klientů - respekt pohlaví, věku, etnické, národnostní nebo náboženské přílušnosti, rodinné/partnerské vztahy;

- stravování klientů - respekt náboženské příslušnosti, stravovací tabu, zvyky, tradice, náboženské svátky a půsty, upřednostňování určitých potravinových komodit, dietní omezení, vyváženost stravy a splnění nutričních požadavků, dostatečný přísun tekutin, zeleniny a ovoce; 
- poskytování zdravotnické/ošetřovatelské péče - zajistit intimitu při vyšetření/ošetření klienta, respekt klientova studu a pohlaví, významnou roli sehrává i postoj klienta vi̊či svému zdraví, vnímání nemoci, předchozí zkušenosti s poskytováním péče již v ČR a v zemi původu klienta, lege artis;

- osobní prohlídky - respektovat intimitu, pohlaví a práva klienta, klienti však musí respektovat provozní řád a nařízení azylových zařízení, kromě svých práv mají i své povinnosti;

- spiritualita a spirituální potřeby - respektovat náboženskou příslušnost, hodnoty, náboženské svátky, půst, vliv filozofie náboženství a religiózních praktik na každodenní život a činnosti klientů, vhodný prostor pro náboženské úkony;

- komunikace - nejdůležitější, nejcitlivější atribut interakce $v$ rámci interpersonálních vztahů $v$ několika úrovních (mezi cizinci/klienty zařízení - zaměstnanci azylových zařízení a ZzC;

- samotná komunikace mezi klienty zařízení; později komunikace s majoritní skupinou $v$ rámci integrace a běžného života cizince s udělenou mezinárodní ochranou aj.;

- východiska pro implementaci transkulturního přistupu respektování lidských práv a svobod, mezinárodní a Evropské úmluvy, legislativa ČR, integrační politika ČR a EU, etické principy a kodexy. 


\section{závěr}

V každém ze zmíněných azylových zařízení a zzC je klientům věnována nezbytná péče, která saturuje všechny bazální potřeby s ohledem na jejich národnostní, etnickou nebo náboženskou přislušnost. Klienti mají možnost věnovat se i různým volnoČasovým aktivitám, výuce českého jazyka, dětem je zajištěna předškolní a školní výchova (způsob zajištění závisí od typu zařizení). Jednotlivá střediska kooperují v rámci národních (jak na bázi státní, tak nestátní podpory a spolupráce) a nadnárodních organizací.

Problematika cizinců přicházejících na území Evropské unie s nadějí na nový začátek života není jednoduchá, avšak těm, kteří dostanou šanci na nový začátek, je nezbytné kontinuálně nabízet pomoc. I proto vznikají centra na podporu integrace cizinců. Dne 1. Července 2009 byla zř́zena čtyři centra na podporu integrace cizinců $v$ České republice. Projekt center je spolufinancován z Evropského integračního fondu. Cílem projektu je zlepšit a koordinovat kontinuální pomoc cizincům žijícím na území České republiky, zejména se jedná - poradenskou, informační a právní pomoc. Pro klienty s minimální nebo pokročilejší znalostí českého jazyka se nabízí kurzy pro lepší osvojení si jazykových dovedností. Sociokulturní kurzy jsou zaměřeny na získání základních informací o České republice, umožní klientovi zorientovat se v oblasti sociálního, zdravotního a vzdělávacího systému v ČR, klient získá základní komunikační dovednosti pro potřeby komunikace s úřady a zaměstnavateli. Internetové pracoviště a knihovna jsou nedílnou součástí významné pomoci cizincưm, k dispozici je možnost naučit se základním počítačovým dovednostem. V knihovně jsou k dispozici také časopisy 
a tiskoviny V několika jazycích. (SUZ MV ČR, Centra na podporu integrace cizinců, 2009)

\section{Seznam bibliografických odkazů}

Český statistický úřad: Demografické aspekty života cizincủ. [online] [cit. 2009-01-12]. Dostupný z www:

http://www2.czso.cz/csu/2002edicniplan.nsf/o/1414-02(casova_rada) -1 _demograficke_aspekty_zivota_cizincu

Český statistický úřad: Cizinci podle typu pobytu, pohlaví a státního občanství - k31. 7. 2009. [online] [cit. 2009-098]. Dostupný z www:

http://www.czso.cz/csu/cizinci.nsf/tabulky/ciz_pocet_cizincu$\underline{001}$

IVANOVÁ, K., ŠPIRUDOVÁ, L., KUTNOHORSKÁ, J. 2005. Integrační politika státu. In IVANOVÁ, $\mathrm{K}$. et al. Multikulturní ošetřovatelství I. Praha: Grada, 2005. s. 84. ISBN 80-247$1212-1$.

Ministerstvo vnitra ČR: Azyl a migrace. Migrační politika České republiky [online] [cit. 2009-01-20]. Dostupný z www: http://www.mvcr.cz/clanek/migrace-novy-clanek-890951.aspx

Ministerstvo vnitra ČR: Azyl a migrace. Přistup $k$ nelegální migraci $v$ České republice a Evropské unii. [online] [cit. 2009-01-12]. Dostupný z www:

http://www.mvcr.cz/clanek/migrace-novy-clanek890951.aspx?q=Y2hudW0 9NQ $\% 3 d \div 3 d$

Ministerstvo vnitra ČR: Odbor azylové a migrační politiky. Mezinárodní ochrana. Azylové řízení v České republice. Průběh správního řízení o udělení mezinárodní ochrany. [online] [cit. 2009-01-26]. Dostupný z www: http://web.mvcr.cz/archiv2008/azyl/azyl.html 
Ministerstvo vnitra ČR: Mezinárodní ochrana. Statistická zpráva - žadatelé o mezinárodní ochranu a azylanti. [online] [cit. 2009-01-20]. Dostupný z wWw:

http://www.mvcr.cz/clanek/mezinarodni-ochrana-983545.aspx Ministerstvo vnitra ČR: Počet dublinských případů květen 2004 - prosinec 2008. [online] [cit. 2009-01-20]. Dostupný z www: wWw.mvcr.cz/soubor/2008-2008-2008-15-pdf.aspx

Ministerstvo vnitra ČR: Odbor azylové a migrační politiky. Terminologický slovník. [online] [cit. 2008-12-11]. Dostupný z www: http://web.mvcr.cz/archiv2008/azyl/slovnik.html

Správa uprchlických zařizení ministerstva vnitra: Správa uprchlických zařízení Ministerstva vnitra České Republiky (SUZ). [online] [cit. 2009-01-12]. Dostupný z www: http://www.suz.cz/pages/6.html

Správa uprchlických zařizení ministerstva vnitra: Aktuality. 20. 10. 2009 [online] [cit. 2009- 23-11]. Dostupný z www: http: //www.suz.cz/

Správa uprchlických zařízení ministerstva vnitra: Výroční zpráva za rok 2007. [online] [cit. 2009-01-12]. Dostupný z WWW :

http://www.suz.cz/downloads/annualReports/vyrocni_zprava_suz_2 $007 . \mathrm{pdf}$

Správa uprchlických zařízení ministerstva vnitra: Centra na podporu integrace cizinců. Poskytované služby. 2009 [online] [cit. 2009-01-12]. Dostupný z www:

http://www.integracnicentra.cz/cz/

ŠIŠKOVÁ, T. 2008. Novodobá emigrace po roce 1989 a na počátku 21. století. In ŠIŠKovÁ, T. Výchova $k$ toleranci a proti rasismu: multikulturní výchova $v$ praxi. 2. vyd. Praha: Portál, 2008. s. 59. ISBN 978-80-7367-182-2. 
Kontakt na hlavního autora:

PhDr. Natália Beharková

Katedra ošetřovatelství

Lékařská fakulta, Masarykova univerzita

Kamenice 3

CZ-625 OO BRNO

nbehar@med.muni.cz 